\title{
The constructivist view of entrepreneurial opportunities: a critical analysis
}

\author{
Stratos Ramoglou • Stelios C. Zyglidopoulos
}

Accepted: 20 May 2014

(C) Springer Science+Business Media New York 2014

\begin{abstract}
The notion that opportunities exist objectively "out there" has been repeatedly assaulted by scholars who counter that opportunities are subjectively constructed or created. This paper intends to restore the balance by bringing the critical strands of inquiry themselves under critical scrutiny. Beyond the formulation of some original lines of critique and the drawing of attention to some foundational yet insufficiently studied issues, this article further contributes the following: (1) it juxtaposes a taxonomical ordering of constructivist approaches; (2) it identifies angles of complementarity and contradiction with the objectivist perspective; and (3) it brings subtle conceptual distinctions into prominence.
\end{abstract}

Keywords Entrepreneurial opportunities - Austrian economics - Philosophy of the social sciences . Constructivist ontology $\cdot$ Conceptual analysis

JEL Classifications $\quad$ B52 $\cdot$ B25 $\cdot$ L26 $\cdot$ B53

S. Ramoglou $(\square)$

Faculty of Business and Law, University of Southampton, Highfield Campus, Southampton, England SO1 71BJ, UK e-mail: s.ramoglou@soton.ac.uk

S. C. Zyglidopoulos

Adam Smith Business School, University of Glasgow, Main Building, Glasgow, Scotland G12 8QQ, UK

e-mail: szyglidopoulos@gmail.com

\section{Introduction}

According to the discovery approach to entrepreneurship, opportunities exist "out there" as objective phenomena awaiting discovery by alert entrepreneurs (e.g., Shane 2003; Kirzner 1979). This dominant view is increasingly under fire from scholars who maintain a constructivist turn in the study of entrepreneurial opportunities (Alvarez et al. 2010). As observed by Wood and McKinley (2010: 67), "constructivist ontology and epistemology is gaining traction within the field of entrepreneurship" since there "appears to be a growing contingent of scholars who feel that constructivism may shed new light on parts of the opportunity phenomenon that the discovery perspective is unable to illuminate."

Broadly speaking, constructivist critics reject the presumed objectivity of opportunities to juxtapose that opportunities are created (constructed, enacted, or manufactured $^{1}$ ) through subjectivist processes of social construction (Alvarez et al. 2014; Garud and Giuliani 2013; Sarason et al. 2010; Sarasvathy 2008; Ardichvili et al. 2003; Bruyat and Julien 2001). In short, on the foundational thesis that "opportunities do not exist until entrepreneurs create them" (Alvarez

\footnotetext{
$\overline{1}$ One should be careful to avoid the supposition that this richness of vocabulary stands for theoretical variation. As stressed by Alvarez and Barney (2013), these words are typically used synonymously and do not signal substantive differences.
} 
et al. 2013: 307), the constructivist reaction brings the creative role of entrepreneurial actors center stage, to juxtapose that it is entrepreneurial agency that is "fundamentally constitutive of [social] structure or external reality" (Korsgaard 2011: 671).

Regardless of any weaknesses of the discovery approach or strengths of the constructivist alternative, it is noteworthy that it is only the former theorizing strand that has undergone severe critical scrutiny. The constructivist approach hardly ever receives any critical attention, as though it serves as a panacea to some of the most important and demanding problems at the heart of entrepreneurial theory (Stuetzer et al. 2014; Pacheco et al. 2010; Kirzner 2009; McMullen et al. 2007; see also Ripsas 1998; Hébert and Link 1989).

This paper intends to restore the balance by drawing attention to the shortcomings of the constructivist conceptualization of opportunities. Alas, this critique cannot unfold along a single line of analysis since there is considerable vagueness about what "opportunity construction" means; a vagueness that arguably results from the fact that constructivist scholars typically use the same terminology to refer to fairly diverse aspects of entrepreneurship-related phenomena. In order, then, to critically examine the constructivist conceptualization of opportunities, we first disentangle the different strands of meaning that constructivists house under the "opportunities are created" thesis and, following this, critically evaluate them separately.

But before we commence, an early clarification is in order. Having maintained that there is considerable confusion within the constructivist benches of scholarship, we do not imply that the objectivist references to opportunity conform to a unique and clear-cut understanding. ${ }^{2}$ As such, it is imperative that we first explicate our understanding of opportunities against which our critique of the constructivist alternative is going to unfold. Our "objectivist" understanding subscribes to a fairly standard economics-based (Kaish and Gilad 1991; Casson 1982) and rather commonsensical understanding

\footnotetext{
${ }^{2}$ There are approaches that reify opportunities (Baron 2004), some that treat them as something quantifiable (Dahlqvist and Wiklund 2012), and others that treat opportunities as "something" more ontologically complicated (Venkataraman et al. 2012). In addition, there is noticeable philosophical confusion surrounding objectivist treatments (Ramoglou 2013).
}

of opportunities (Kim and Mauborgne 2005; Porter 1980) that may be concisely articulated as follows: opportunities exist "out there" as unfulfilled market needs, the satisfaction of which can generate revenue that exceeds the production cost.

\section{Disentangling the variety of meanings}

A careful reading of constructivist discourse readily exposes considerable ambiguity and imprecision around the ways in which opportunities are said to be created. While Sarasvathy $(2001,2012)$ frames opportunities as the new worlds created by entrepreneurial effectuation, Gartner (2012: 26) advises that opportunity is created from entrepreneurial sensemaking capabilities, whereas Korsgaard recommends that "an opportunity may be enacted, e.g., as a material artifact embodied in the text of a business plan" (2011: 673). Elsewhere, we find Dimov (2011) suggesting that opportunity can be traced in creative entrepreneurial deeds, or Garud and Giuliani arguing for a "'subtext' of creative energy that is the wellspring of entrepreneurial opportunities" (2013: 158).

In disentangling the variety of meanings, we submit that they essentially boil down to one of four senses of "opportunity creation," each alluding to quite different aspects of the entrepreneurial process. Specifically, they may refer to

(1) The imaginative inception of an opportunity;

(2) The formation of the conditions conducive to the creation of entrepreneurial goods;

(3) The production of entrepreneurial goods; or

(4) The engineering of demand for produced goods.

In the following sections, we will critically evaluate the idea that opportunities do not exist "out there" but have to be constructed, in examining the meaningfulness and/or plausibility of interpreting the four aforementioned stages through constructivist lenses.

To this end, we may further denominate as $\mathrm{O}_{1}, \mathrm{O}_{2}$, $\mathrm{O}_{3}$, and $\mathrm{O}_{4}$ the senses of "opportunity creation" corresponding to each of the above stages. More precisely, $\mathrm{O}_{1}$ refers to the approaches that lean toward constructivism on the (mis)understanding that the subjectivity of the opportunity-identification process contradicts the intelligibility of their external existence. $\mathrm{O}_{2}$ refers to the (careless) practice of naming 
opportunity creation, the creation of the organizational conditions required for the production of entrepreneurial products (or services). $\mathrm{O}_{3}$ covers cases in which the creation of entrepreneurial products is (equally misleadingly) labeled as opportunity creation. Lastly, $\mathrm{O}_{4}$ refers to perspectives that deny that entrepreneurial opportunities (qua market demand) preexist "out there" to (dubiously) recommend that demand for entrepreneurial products is actually engineered by skillful entrepreneurial deeds.

\section{3 "Opportunities exist purely subjectively"}

When referring to the early stages of the entrepreneurial process, opportunities are said to be created in the sense that they "emerge out of the imagination of individuals" (Dimov 2004: 150) and reside "only in the individual's mind" (Chandler et al. 2003: 402). It is submitted that this sense is fine to the extent that it reacts to crude conceptualizations of opportunity identification according to which opportunities are seen literally with our eyes (e.g., Ucbasaran et al. 2008: 157).

Our strong caveat concerns the following: from the correct recognition of "the subjective element in pursuing opportunities" (Buenstorf 2007: 323), it does not follow that opportunities do not exist "out there." This conclusion only betrays commitment to extravagant, idealist philosophical positions that treat the external world as reducible to the constructs of the individual and/or collective imagination. And although exaggerated theses of this kind are quite fashionable in modern philosophical literature (Hacking 1999; Searle 1998), they remain deeply flawed (Boghossian 2006; Searle 1995).

In the context of entrepreneurial opportunities, a fine expression of the idealist mind-set is offered by Alvarez and Barney who maintain that, in virtue of their socially constructed nature, opportunities "do not exist independent of the entrepreneur's perceptions" (2007: 15). Exposing the fallacies underlying this idealist perspective is paramount, given especially that pertinent philosophical intuitions ramify over several streams of constructivist thought (see especially $\mathrm{O}_{4}$ ).

The idealist conclusion is not only strikingly counterintuitive. Most importantly, it is logically unwarranted. The fact that our knowledge of the external world is mind-dependent does not mean that the world itself must be a projection of our mental processes. No doubt, our perceptions of the world are hardly ever direct and unmediated. Different cognitive systems process external input variously, whereas cultural backgrounds and preconceptions certainly influence how we make sense of the world. Yet, from this realization, it does not follow that objective reality is a mere projection of our mental processes. It only follows that our interpretations of what is objectively "out there" are dependent upon subjective factors. Reality itself remains "out there" and objectively real, notwithstanding any mismatches between our perceptions of this reality and the reality as it exists in itself (Bhaskar 1978).

It follows that entrepreneurial opportunities-as unfulfilled market needs-exist "out there," regardless of whether potential entrepreneurs have perceived them or not, or whether they have the willingness to exploit them, and so forth (Shane and Venkataraman 2000; Koellinger et al. 2007). They may remain unperceived and unexploited, just as archeological artifacts may remain undiscovered.

On a more moderate reading of the constructivist critique, it does not dispute the objective existence of the external world, but the presumed objectivity of its social dimensions. In other words, a constructivist scholar need not fall for a wholesale rejection of the existence of an external realm, but may simply restrain critical attention in questioning the reality of the social world.

Without doubt, the social world does not exist in the same way that elements of the natural world exist. Markets or currencies are nothing like rocks or trees. Still, however, from the acknowledgment that social reality is dependent upon the ways that we think about it, it does not follow that it is less real, let alone that it exists in virtue of entrepreneurs' thinking. It only follows that it is differently real and that we ought to distinguish between different kinds of reality (Searle 1995, 2002). Our perceptions may participate in sustaining the reality of social objects; yet, their existence neither requires individual acts of perception, nor is it reducible to the (collective) activity of human minds (see also $\mathrm{O}_{4}$ below) (Bhaskar 1998).

To respond to Alvarez and Barney's (2007: 15) assertion that "opportunities are social constructions that do not exist independent of the entrepreneur's perceptions", given that they are nothing like physical objects (Alvarez et al. 2014), they may indeed exist as 
social constructions (or comprise social constructions of sorts). But the conclusion that they do not themselves possess ontological weight, or that they do not exist independently from the perception of any given entrepreneur, is a non sequitur. ${ }^{3}$

In addition, to connect to the earlier quotation expressing the aspiration "that constructivism may shed new light on parts of the opportunity phenomenon that the discovery perspective is unable to illuminate" (Wood and McKinley 2010: 67), up to now, our analysis has cast a shadow of doubt on the illuminating potential of constructivist philosophy. In the forthcoming section, we will, moreover, ascertain that $\mathrm{O}_{2}$ and $\mathrm{O}_{3}$ do not even manage to shed any light at all onto the "opportunity phenomenon."

\section{Novel insight or linguistic innovations?}

According to our taxonomic account, the $\mathrm{O}_{2}$ sense of opportunity creation refers to the creation of the financial and/or institutional conditions conducive to the production of entrepreneurial supplies, and $\mathrm{O}_{3}$ alludes to the creative processes involved in the production of these entrepreneurial supplies (Cornelissen et al. 2012; Cornelissen and Clarke 2010; Alvarez et al. 2010; Wood and McKinley 2010). Both these aspects of the entrepreneurial process may indeed be creative (and often require the deployment of creative skills), but describing them as opportunity creation does not seem to extend our theoretical reach in any meaningful manner. It only appears to stretch language in ways that pretend to offer novel theoretical insight when, as a matter of fact, they only manage to add confusion (compare with Garud and Giuliani 2013; Alvarez and Barney 2010). Let us unpack this.

Highlighting the social aspects involved in setting up the organizational structures required for the supply of entrepreneurial products should, unquestionably, be commended. Not least, it adds a valuable drop of realism that is often absent from abstracted from the

\footnotetext{
${ }^{3}$ If subjectivist scholars tend to suppose that, by virtue of being part of a socially constructed reality, opportunities do not truly exist "out there," it appears that objectivists tend to reject subjectivist references for an equally unfounded reason: for fear that without treating opportunities as though they exist as physical objects, we are left without an adequately real domain to study (see Shane 2012).
}

organizational world models of entrepreneurial activity (see, for example, Kirzner 1979). Most innovative ventures do not simply demand the recognition of a possible profit opportunity. They additionally require the creation $\left(\mathrm{O}_{2}\right)$ of appropriate organizational structures for the creation $\left(\mathrm{O}_{3}\right)$ of the goods required for their exploitation. Moreover, it is also reasonable to acknowledge that these episodes of creation are not reducible to mechanical deeds. Genuine creativity should often be required during the production of innovative goods or efforts targeted at acquiring the socioeconomic structures necessary for their production $^{4}$ (Schumpeter 1983).

What is, nonetheless, highly questionable is whether it is sensible, or at any rate useful, to refer to these creative episodes as opportunity creation. Consider, for example, Sarasvathy et al. (2010: 92), who frame the creation of opportunity as the creation of the "concrete products, services, and institutions that constitute the economy." What are created are not opportunities but organizations, institutions, products, services, and so on. To say that we "create opportunity" when we "create products" is to basically let the word "opportunity" parasitically take the place of the word "products." This misleading linguistic practice is also common in reading Schumpeter as the proponent of a constructivist understanding of opportunities (cf. Kirzner 1999). Buenstorf's mode of reasoning is instructive:

Schumpeter does not explicitly feature the opportunity concept. Instead, his point of departure is the notion of innovation characterized as "new combination" (Schumpeter 1911/[1983]). The entrepreneur is an individual who creates a new combination and pursues it in the market... Clearly, the creation of a new combination can be interpreted as the creation of an entrepreneurial opportunity (2007: 325).

In stark contrast to Buenstorf's assessment, we submit that it is far from clear that the creation of a new

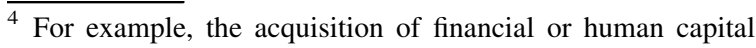
may require the skillful manipulation of symbols, creative preparation of a business plan, the deployment of rhetorical devices, and all sorts of micro-institutional processes (Powell and Colyvas 2008). And this should be especially the case if we are talking about nascent firms lacking legitimacy (Aldrich and Fiol 1994) or small businesses in eras of financial insecurity (OECD 2009).
} 
combination may be meaningfully "interpreted" as the creation of an entrepreneurial opportunity. On the contrary, we argue that this undisciplined use of language only begets confusion by sustaining the misleading impression that we have competing viewpoints of the opportunity phenomenon just because we rely upon similar forms of expression.

After all, we should not forget that the objectively existing opportunities that discovery scholars have in mind are opportunities for profit (Kirzner 1973; Casson 1982). As such, not only the $\mathrm{O}_{2}$ and $\mathrm{O}_{3}$ senses of opportunity creation do not compete with the idea that opportunities exist "out there." In truth, it is reasonable to suppose that not many discovery scholars would object to the thesis that creative action may be involved in the exploitation of objective (profit) opportunities. To recap, when entrepreneurs create artifacts at the supply side of the economy, it is simply unclear what it may intelligibly mean to additionally say that they create entrepreneurial opportunities as well. This is especially the case given that we could simply rephrase this by saying that in mobilizing/ recombining socioeconomic resources, entrepreneurs create the means by which preexistent opportunities can be exploited.

In closing this section, it is tempting to conjecture that these linguistic innovations are essentially a side effect of forced attempts to make original theoretical contributions. To anticipate scholars who may counter that this line of critique guards against theoretical pluralism, and encourages theoretical stagnation and isomorphism, we should note that this is far from the case. Pluralism is unquestionably desirable. However, the mark of an original contribution is not reducible to a novel recombination of words in webs of signification. In order for our academic discourses to qualify as novel theoretical perspectives as well, they should (among other things) satisfy the criterion of meaningfulness.

\section{Opportunities are created in generating market demand}

Previously, we argued that it does not make very good sense to label the creative processes involved in the supply of entrepreneurial goods as opportunity creation. By contrast, however, we may meaningfully say that (profit) opportunities have to be created when denying the preexistence of demand for products and invoking the creative processes required for its generation. For instance, it is perfectly intelligible to say that opportunities are created in the sense that "[t]here is no preexisting market to be analyzed and penetrated" (Korsgaard 2011: 673) but "markets have to be invented, fabricated, and constructed" (Sarasvathy 2003: 308).

Although this sense of opportunity construction $\left(\mathrm{O}_{4}\right)$ truly manages to provide a competing outlook to the objectivist perspective, it fails on another front. Specifically, it fails to afford a superior, and more sustainable, "window" on basic aspects of the entrepreneurial phenomenon. This assessment stands in need of justification.

The (often only implicitly held) presupposition that market demand is an agent-dependent phenomenon contingent upon the "worldmaking" capacities of entrepreneurs (Sarasvathy 2012) is at odds with our ordinary understanding of the realistic. It runs contrary to the trust that we typically place in our imagination about what is possible within our world and implicitly concedes to the (unrestrictedly) voluntarist view that any type of crazy venture is (in principle) profitable. This is unrealistic for the reason that, although we may imaginatively entertain a multitude of possibilities, we simply know that the realm of the naturally possible is narrower than the realm of the imaginable. For example, although we may have no problem imagining the creation of a company with the profit-making potential of an Apple or a Google, we are (prereflectively) aware that our imagination is not a definitive guide to what is genuinely possible within the boundaries of the real world. We may often daydream. But we do not typically let ourselves fall for any sort of fantasy.

Moreover, "worldmaking" fantasies are also accountable for committing the fallacy of "social atomism." A lucid articulation of this methodological fallacy may be found in Knight's critique of the presuppositions of neoclassical economists regarding perfect competition. According to the modeling practices of neoclassical economics:

there is no exercise of constraint over any individual by another individual or by "society"... Every member of society is to act as an individual only, in entire independence of all other persons. To complete his (sic) independence he must be free from social wants, 
prejudices, preferences, or repulsions, or any values which are not completely manifested in market dealing (Knight 1921: 77-78).

To apply this critique in our case, the idea that we can willingly manipulate market conditions presupposes that there are no objective constraints over aspiring entrepreneurs. An entrepreneur's prospects of success are ultimately dependent upon one's wishes and actions, since one can impose the market demand that $\mathrm{s} /$ he desires. Social wants, prejudices, preferences, repulsions, or values are negligible or, at any rate, transformable by means of appropriate entrepreneurial interventions. Even further, unrealistic stances of this sort are additionally accountable for being the expressions of dogmatic worldviews. To assert or imply that the imaginable is equivalent to the possible is to subscribe to a metaphysical dogma that is hardly ever justifiable by means of rational analysis.

Despite the lack of plausibility, the fallacies that they commit, or the metaphysical dogmatisms that they presuppose, one should not downplay the fact that constructivist extravagances may be appealing for quite different reasons (cf. Bigo 2008). Searle's (1995; 1998) observations into the alluring nature of constructivist ways of thought are potentially insightful in understanding their academic popularity. He says:

It is somehow satisfying to our will to power to think that "we" make the world, that reality itself is but a social construct, alterable at will and subject to future changes as "we" see fit. Equally, it seems offensive that there should be an independent reality of brute facts-blind, uncomprehending, indifferent, and utterly unaffected by our concerns. And all of this is part of the general intellectual atmosphere that makes [excessive constructivist ontologies] seem intellectually acceptable, even exciting (1995: 158).

To recast this reasoning, it is, indeed, satisfying to feel that we can construct the markets that we desire, as though the possible is dependent upon our imagination and our will, and our aspirations are unrestrained by objective forces. From this standpoint, it is tempting to conjecture that constructivist approaches of this kind may also be appealing to the students of entrepreneurship for the reason that it is understandably uplifting to be told that entrepreneurship affords the means for constructing the worlds that we desire.

\section{Conclusion}

The discovery approach to entrepreneurship has suffered quite severe and extensive attacks (see Korsgaard 2013), as opposed to the constructivist alternative which has not yet received adequate critical attention. The present paper has endeavored to restore this balance. Having brought some initial order to the constructivist take on opportunities, we carefully examined the extent to which the constructivist alternative may pave the way toward an advanced conceptualization of entrepreneurial opportunities.

In general, the results of the analysis were largely negative. The idea that opportunities exist "out there" as unfulfilled market needs (with a profit potential) seems the most secure foundation of an opportunitycentered study of entrepreneurship. True, creative deeds may be required in the development of entrepreneurial ventures or in trying to generate profits. But these acts need not be understood as constitutive of opportunities themselves. Instead, they may simply be conceptualized as efforts capable of unleashing preexisting opportunities - akin to the fertilizers enabling seeds to grow into healthy plants.

At this point, it should be emphasized that our present exposition was made in the spirit of rational deliberation, and by no means do we insinuate that we have said the last word on matters so foundational to entrepreneurial discourse. We far more modestly hope to have planted some valuable seeds of skepticism, opened up new arenas for rational dispute, and directed attention toward some inadequately reflected-upon issues at the very conceptual foundations of entrepreneurship studies. Put differently, we do not imply that objectivist approaches cannot be improved, or that a more refined and philosophically sophisticated constructivism is not possible. Our present analysis has only found that the constructivist developments-as they currently stand-do not appear quite compelling, and considerable work remains to be done if they are to afford a credible alternative to the traditional, objectivist perspective.

In closing, it is worth mentioning that beyond its more concrete contributions, the current study was significantly motivated by the assessment that - contrary to customary appraisals-what is crucially missing in entrepreneurial discourse (e.g., when compared to related management-based disciplines) 
is not principally theory, databases, effort, imagination, intelligence, or institutional support. Far from that, our guiding intuition had been that an obstacle stalling the scientific progress of entrepreneurship studies (Arend 2014) is insufficient attention to matters standing in the thin line between empirical inquiry and theory development, such as conceptual clarity and order, or meta-theoretical reflexivity and analysis. Put from a slightly different angle, as entrepreneurship researchers, it seems that we often overlook the notion that, if the vehicle for moving forward along the path of scientific maturity lies in empirical and theoretical inquiries, the vehicle itself is blind and cannot be expected to progress without being orientated by careful and patient analyses into basic aspects of our conceptual schemes (see also Miller and Tsang 2010).

If so, we far more often have to step back and critically reflect upon matters that cannot be settled by mere (or more) substantive research with an eye toward forms of understanding that best resonate with the pre-theoretical understandings that we most reliably trust in our non-academic, everyday moments. From a philosophy of science standpoint, to act accordingly is to take the safest way to becoming a genuinely scientific discipline-a subject matter truly worthy of the intellectual respect of the broader social sciences academy.

\section{References}

Aldrich, H. E., \& Fiol, C. M. (1994). Fools rush in? The institutional context of industry creation. Academy of Management Review, 19(4), 645-670.

Alvarez, S. A., \& Barney, J. B. (2007). Discovery and creation: Alternative theories of entrepreneurial action. Strategic Entrepreneurship Journal, 1(1), 11-26.

Alvarez, S. A., \& Barney, J. B. (2010). Entrepreneurship and epistemology: The philosophical underpinnings of the study of entrepreneurial opportunities. The Academy of Management Annals, 4(1), 557-583.

Alvarez, S. A., \& Barney, J. B. (2013). Epistemology, opportunities, and entrepreneurship: Comments on Venkataraman et al. (2012) and Shane (2012). Academy of Management Review, 38(1): 154-157.

Alvarez, S. A., Barney, J. B., \& Young, S. L. (2010). Debates in entrepreneurship: Opportunity formation and implications for the field of entrepreneurship. In Z. J. Acs \& D. B. Audretsch (Eds.), Handbook of entrepreneurship research: An interdisciplinary survey and introduction (2nd ed., pp. 23-46). New York: Springer.
Alvarez, S. A., Barney, J. B., \& Anderson, P. (2013). Forming and exploiting opportunities: The implications of discovery and creation processes for entrepreneurial and organizational research. Organization Science, 24(1), 301-317.

Alvarez, S. A., Barney, J., McBride, R., \& Wuebker, R. (2014). Realism in the study of entrepreneurship. Academy of Management Review, 39(2), 227-231.

Ardichvili, A., Cardozo, R., \& Ray, S. (2003). A theory of entrepreneurial opportunity identification and development. Journal of Business Venturing, 18(1), 105-123.

Arend, R. J. (2014). Promises, premises. An alternative view on the effects of the Shane and Venkataraman 2000 AMR note. Journal of Management Inquiry, 23(1), 38-50.

Baron, R. A. (2004). The cognitive perspective: A valuable tool for answering entrepreneurship's basic "why" questions. Journal of Business Venturing, 19(2), 221-239.

Bhaskar, R. (1978). A realist theory of science. Sussex: Harvester Press.

Bhaskar, R. (1998). The possibility of naturalism: A philosophical critique of the contemporary human sciences (3rd ed.). London: Routledge.

Bigo, V. (2008). Explaining modern economics (as a microcosm of society). Cambridge Journal of Economics, 32(4), 527-554.

Boghossian, P. (2006). Fear of knowledge: Against relativism and constructivism. Oxford: Clarendon Press.

Bruyat, C., \& Julien, P. A. (2001). Defining the field of research in entrepreneurship. Journal of Business Venturing, 16(1), $165-180$.

Buenstorf, G. (2007). Creation and pursuit of entrepreneurial opportunities: An evolutionary economics perspective. Small Business Economics, 28(4), 323-337.

Casson, M. (1982). The entrepreneur. Totowa, NJ: Barnes \& Noble Books.

Chandler, G. N., DeTienne, D., \& Lyon, D. W. (2003). Outcome implications of opportunity creation/discovery processes. Presented at the Babson-Kauffman entrepreneurship research conference. Wellesley, MA: Babson College.

Cornelissen, J. P., \& Clarke, J. S. (2010). Imagining and rationalizing opportunities: Inductive reasoning, and the creation and justification of new ventures. Academy of Management Review, 35(4), 539-557.

Cornelissen, J. P., Clarke, J. S., \& Cienki, A. (2012). Sensegiving in entrepreneurial contexts: The use of metaphors in speech and gesture to gain and sustain support for novel business ventures. International Small Business Journal, 30(3), 213-241.

Dahlqvist, J., \& Wiklund, J. (2012). Measuring the market newness of new ventures. Journal of Business Venturing, 27(2), 185-196.

Dimov, D. (2004). The individuality of opportunity recognition: A critical review and extension. In J. E. Butler (Ed.), Opportunity identification and entrepreneurial behavior (pp. 135-162). Greenwich, CT: IAP.

Dimov, D. (2011). Grappling with the unbearable elusiveness of entrepreneurial opportunities. Entrepreneurship Theory and Practice, 35(1), 57-81.

Gartner, W. B. (2012). Entrepreneurship as organization creation. In D. Hjorth (Ed.), Handbook on organizational entrepreneurship (pp. 21-30). Cheltenham: Edward Elgar. 
Garud, R., \& Giuliani, A. (2013). A narrative perspective to entrepreneurial opportunities. Academy of Management Review, 38(1), 157-160.

Hacking, I. (1999). The social construction of what? Cambridge, MA: Harvard University Press.

Hébert, R. F., \& Link, A. N. (1989). In search of the meaning of entrepreneurship. Small Business Economics, 1(1), 39-49.

Kaish, S., \& Gilad, B. (1991). Characteristics of opportunities search of entrepreneurs vs. executives: Sources, interests, and general alertness. Journal of Business Venturing, 6(1), $45-61$.

Kim, W. C., \& Mauborgne, R. (2005). Blue ocean strategy: How to create uncontested market space and make the competition irrelevant. Boston: Harvard Business School Press.

Kirzner, I. M. (1973). Competition and entrepreneurship. Chicago: University of Chicago Press.

Kirzner, I. M. (1979). Perception, opportunity and profit. Chicago: University of Chicago Press.

Kirzner, I. M. (1999). Creativity and/or alertness: A reconsideration of the Schumpeterian entrepreneur. Review of Austrian Economics, 11(1-2), 5-17.

Kirzner, I. M. (2009). The alert and creative entrepreneur: A clarification. Small Business Economics, 32(2), 145-152.

Knight, F. H. (1921). Risk, uncertainty and profit. Chicago: University of Chicago Press.

Koellinger, P., Minniti, M., \& Schade, C. (2007). I think I can, I think I can: Overconfidence and entrepreneurial behavior. Journal of Economic Psychology, 28(4), 502-527.

Korsgaard, S. T. (2011). Entrepreneurship as translation: Understanding entrepreneurial opportunities through actor-network theory. Entrepreneurship and Regional Development, 23(7-8), 661-680.

Korsgaard, S. (2013). It's really out there: A review of the critique of the discovery view of opportunities. International Journal of Entrepreneurial Behaviour \& Research, 19(2), 130-148.

McMullen, J. S., Plummer, L. A., \& Acs, Z. J. (2007). What is an entrepreneurial opportunity? Small Business Economics, 28(1), 273-283.

Miller, K. D., \& Tsang, E. W. K. (2010). Testing management theories: Critical realist philosophy and research methods. Strategic Management Journal, 32(2), 139-158.

Organisation for Economic Co-operation and Development (OECD). (2009). The impact of the global crisis on SME and entrepreneurship financing and policy responses. Paris: Organisation for Economic Co-operation and Development Publications.

Pacheco, D. F., Dean, T. J., \& Payne, D. S. (2010). Escaping the green prison: Entrepreneurship and the creation of opportunities for sustainable development. Journal of Business Venturing, 25(5), 464-480.

Porter, M. E. (1980). Competitive strategy: Techniques for analyzing industries and competitors. New York: The Free Press.

Powell, W. W., \& Colyvas, J. A. (2008) Microfoundations of institutional theory. In Greenwood, R., Oliver, C., Suddaby, R., \& K. Sahlin (Eds.), Sage handbook of organizational institutionalism (pp. 276-298). Thousand Oaks, CA: Sage.

Ramoglou, S. (2013). On the misuse of realism in the study of entrepreneurship. Academy of Management Review, 38(3), 463-465.
Ripsas, (1998). Towards an interdisciplinary theory of entrepreneurship. Small Business Economics, 10(2), 103-115.

Sarason, Y., Dillard, J. F., \& Dean, T. (2010). How can we know the dancer from the dance? Reply to "Entrepreneurship as the structuration of individual and opportunity: A response using a critical realist perspective". Journal of Business Venturing, 25(2), 238-243.

Sarasvathy, S. D. (2001). Causation and effectuation: Toward a theoretical shift from economic inevitability to entrepreneurial contingency. Academy of Management Review, 26(2), 243-263.

Sarasvathy, S. D. (2003). Constructing corridors to economic primitives: entrepreneurial opportunities as demand-side artefacts. In J. Butler (Ed.), Opportunity identification and entrepreneurial behavior (pp. 291-312). Greenwich, CT: Information Age Publishing.

Sarasvathy, S. D. (2008). Effectuation: Elements of entrepreneurial expertise. Cheltenham: Edward Elgar.

Sarasvathy, S. D. (2012). Worldmaking. In Corbett, A. C., \& J. A. Katz (Eds.), Advances in entrepreneurship, firm emergence and growth: Entrepreneurial action (pp. 1-24). Bingley, UK: Emerald Group Publishing Limited.

Sarasvathy, S. D., Dew, N., Velamuri, R., \& Venkataraman, S. (2010). Three views of entrepreneurial opportunity. In Z. J. Acs \& D. B. Audretsch (Eds.), Handbook of entrepreneurship research: An interdisciplinary survey and introduction (2nd ed., pp. 77-98). New York: Springer.

Schumpeter, J. A. (1983). The theory of economic development: An inquiry into profits, capital, credit, interest, and the business cycle. New Brunswick: Transaction Publishers.

Searle, J. R. (1995). The construction of social reality. London: Penguin.

Searle, J. R. (1998). Mind, language, and society: Philosophy in the real world. New York: Basic Books.

Searle, J. R. (2002). Consciousness and language. Cambridge: Cambridge University Press.

Shane, S. (2003). A general theory of entrepreneurship. Northampton, MA: Edward Elgar.

Shane, S. (2012). Reflections on the 2010 AMR decade award: Delivering on the promise of entrepreneurship as a field of research. Academy of Management Review, 37(1), 10-20.

Shane, S., \& Venkataraman, S. (2000). The promise of entrepreneurship as a field of research. Academy of Management Review, 25(1), 217-226.

Stuetzer, M., Obschonka, M., Brixy, U., Sternberg, R., \& Cantner, U. (2014). Regional characteristics, opportunity perception and entrepreneurial activities. Small Business Economics, 42(2), 1-24.

Ucbasaran, D., Westhead, P., \& Wright, M. (2008). Opportunity identification and pursuit: Does an entrepreneur's human capital matter? Small Business Economics, 30(2), 153-173.

Venkataraman, S., Sarasvathy, S., Dew, N., \& Forster, W. R. (2012). Reflections on the 2010 AMR decade award: Whither the promise? Moving forward with entrepreneurship as a science of the artificial. Academy of Management Review, 37(1), 21-33.

Wood, M. S., \& McKinley, W. (2010). The production of entrepreneurial opportunity: A constructivist perspective. Strategic Entrepreneurship Journal, 4(1), 66-84. 